\title{
The lectin isolated from Lonchocarpus araripensis seed elicits endothelium- dependent vasorelaxation
}

\section{A lectina isolada de sementes de Lonchocarpus araripensis promove efeito vasorelaxante dependente de endotélio}

Alana de Freitas Pires ${ }^{1,2}$, Lívia Mendes de Almeida ${ }^{1}$, Debora Helen Marques da Silva ${ }^{1}$, Gabriela Fernandes Oliveira Marques ${ }^{1}$, João Batista Cajazeiras ${ }^{3,4}$, Cornevile Correia-Neto ${ }^{3}$, Kyria Santiago Nascimento ${ }^{3}$, Benildo Sousa Cavada ${ }^{3}$; Ana Maria Sampaio Assreuy $^{1}$

1. Instituto Superior de Ciências Biomédicas (ISCB) da Universidade Estadual do Ceará (UECE), Campus do Itaperi, Ceará, Brasil. 2. Centro Universitário Estacio do Ceará (ESTACIO-FIC), Campus Via Corpvs, Ceará, Brasil. 3. Departamento de Bioquímica e Biologia Molecular da Universidade Federal do Ceará (UFC), Ceará, Brasil. 4. Instituto Superior de Teologia Aplicada (INTA), Ceará, Brasil.

\begin{abstract}
Background: The vasorelaxant effect of lectins from leguminous plants (Diocleinae subtribe) is well described. However, this effect has been little explored for lectins isolated from Dalbergieae tribe, except for that of Vatairea guianensis, that induces vasorelaxation involving nitric oxide and the lectin domain. Objective: To evaluate the vasorelaxant effect of a lectin isolated from Lonchocarpus araripensis (LAL), Dalbergieae tribe, and the involvement of the lectin domain and endothelium derived relaxing factors. Methods: Aortic rings of Wistar rats $(250-300 \mathrm{~g})$ were mounted in organ bath and mantained in physiological conditions (CEUA No.10130208-8/40). LAL $(0.1-100 \mu \mathrm{g} / \mathrm{ml}$ ) was added to phenylephrine $(0.1 \mu \mathrm{M})$-contracted tissues with either endothelium intact or denuded. In order to investigate the mechanisms of LAL relaxation, inhibitors of NOS (L-NAME: $100 \mu M)$, cyclooxygenase (indomethacin: $10 \mu M$ ), or potassium channels (TEA: $5 \mathrm{mM}$ ) were added to endothelized tissues 30 min before contraction. The involvement of lectin domain was assessed by previous incubation of LAL (30 $\mu \mathrm{g} / \mathrm{ml})$ with GlcNAc $(0.1 \mathrm{M})$. Results: LAL $(0.1-100 \mu \mathrm{g} / \mathrm{ml})$ induced relaxation only in endothelized aorta, being maximal at $100 \mu \mathrm{g} / \mathrm{ml}(62.57 \pm 7.8 \%)$. The relaxant effect induced by LAL at $30 \mu \mathrm{g} / \mathrm{ml}(52.49 \pm 10.32 \%)$ was abolished by previous incubation with GlcNAc. LAL relaxant effect (IC50 $9.75 \pm 7.1$ ) was partially reversed by indomethacin (IC50 LAL + indomethacin: $30.47 \pm 10.93$ ) and was abolished by L-NAME or TEA. Conclusion: LAL exhibits vasorelaxant activity in contracted endothelized aorta of rats, involving the lectin domain, muscarinic receptor of acetylcholine and endothelial derived relaxing factors.
\end{abstract}

Key words: Lonchocarpus araripensis. Lectin. Vasorelaxant effect. Endothelium-derived relaxing factors. Lectin domain.

\section{Resumo}

Introdução: 0 efeito vasorrelaxante de lectinas de plantas leguminosas (Subtribo Diocleinae) já é bem descrito, embora pouco explorado para lectinas isoladas da tribo Dalbergieae, com exceção da lectina de Vatairea guianensis, que induz relaxamento com envolvimento de óxido nítrico e do domínio lectínico. Objetivo: Avaliar o efeito vasorrelaxante da lectina isolada de Lonchocarpus araripensis (LAL), tribo Dalbergieae, e o envolvimento do domínio lectínico e de fatores relaxantes derivados do endotélio (EDRF). Métodos: Anéis de aorta de ratos Wistar (250-300 g) foram montados em banho de órgãos em condições fisiológicas (Tyrode, $37^{\circ} \mathrm{C}, 95 \%$ de 02 e $5 \%$ de CO2, $\mathrm{pH}=7,4$ ) (CEUA No. 10130208-8/40). LAL (0,1-100 $\mu \mathrm{g} / \mathrm{ml}$ ) foi adicionada a tecidos précontraídos com fenilefrina $(0,1 \mu \mathrm{M})$ com ou sem endotélio. Para investigar os mecanismos de relaxamento, foram adicionados inibidores de NOS (L-NAME: $100 \mu \mathrm{M}$ ), guanilato ciclase (ODQ: $10 \mu \mathrm{M}$ ), receptor muscarínico (atropina: $1 \mu \mathrm{M}$ ), ciclooxigenase (indometacina: $10 \mu \mathrm{M}$ ) ou canais de potássio (TEA: $5 \mathrm{mM}$ ) aos tecidos endotelizados 30 minutos antes da contração. 0 envolvimento do domínio lectínico foi avaliado por incubação prévia da LAL (30 $\mu \mathrm{g} / \mathrm{ml})$ com GlcNAc $(0,1 \mathrm{M})$. Resultados: LAL $(0,1-100 \mu \mathrm{g} / \mathrm{ml})$ relaxou apenas anéis de aorta endotelizadas, com efeito máximo na dose de $100 \mu \mathrm{g} / \mathrm{ml}(62,57 \pm 7,8 \%)$. O efeito relaxante da LAL a $30 \mu \mathrm{g} / \mathrm{ml}(52,49 \pm 10,32 \%)$ foi abolido por incubação prévia com GlcNAc, atropina ou ODQ. 0 relaxamento da LAL (IC50 9,75 \pm $7,1)$ a 10,30 e $100 \mu \mathrm{g} / \mathrm{ml}$ foi parcialmente revertido por indometacina (IC50 LAL + indometacina: 30,47 $\pm 10,93$ ) e abolido por L-NAME e TEA. Conclusão: A LAL exibe atividade vasorrelaxante em aorta endotelizada de ratos, no estado contraído, envolvendo o domínio lectínico, receptor muscarínico e fatores relaxantes derivados do endotélio.

Palavras-chave s: Lonchocarpus araripensis. Lectina. Efeito vasorrelaxante. Fatores relaxantes derivados do endotélio. Domínio Lectínico.

\section{INTRODUCTION}

Lectins are proteins possessing at least one non-catalytic lectin domain by which they reversibly bind to specific mono or oligosaccharides ${ }^{1}$. Plant lectins isolated from the Leguminosae family have been considered important tools in biological models, since they present structural similarities but differ in their activities ${ }^{2}$.
Leguminous lectins belonging to Diocleinae subtribe are well described regarding their in vitro vasodilator effect, which involves the lectin domain and endothelial-derived relaxant factors, specially nitric oxide $(\mathrm{NO})^{3-6}$. However, for lectins isolated from the tribe Dalbergieae, the vasodilator effect has been little explored, except for that isolated from Vaitarea 
guianensis, which induces relaxation via NO and the lectin domain ${ }^{7}$. Particularly, only few investigations report the effect of lectins of the genus Lonchocarpus in nociception and inflammation models, but there is no data about its in vitro vasodilator effects ${ }^{8-11}$. In this line, investigations of new vasodilator substances could ameliorate several symptoms of pathological conditions involving endothelial disfunction, such as diabetes and hypertension.

The aim of the present study was to investigate the vasorelaxant effect of Lonchocarpus araripensis lectin (LAL) and the involvement of the lectin domain and endothelium-derived relaxing factors (EDRF).

\section{MATERIALS AND METHODS}

\section{Materials}

$\mathrm{N}$-acetylglucosamine (GlcNAc), indomethacin, Nw- nitro-Larginine-methyl ester (L-NAME), 1H-[1,2,4]Oxadiazolo-[4,3-a] quinoxalin-1-one (ODQ), phenylephrine (PE), acetylcholine (ACh), tetraethylammonium (TEA) and atropine were purchased from Sigma Chemical (St. Louis, MO, USA). All drugs and the lectin were solubilized in $0.15 \mathrm{M}$ sterile $\mathrm{NaCl}$ (saline), except for indomethacin, which was dissolved in dimethyl sulfoxide up to $10 \%$ of total volume and then in saline.

\section{Animals}

Male Wistar rats (250-300 g) were maintained with a 12/12 h light/dark cycle at 25 oc with free access to food and water. The experimental protocols were approved by the Institutional Animal Care and Use Committee of the State University of Ceará (CEUA/UECE No. 10130208-8/40).

\section{Lectin}

LAL was isolated from seeds of Lonchocarpus araripensis (family Leguminosae, subfamily Faboideae, tribe Dalbergiae) by affinity chromatography followed by ion exchange chromatography (DEAE-Sephacel) $^{11}$.

\section{Tissue preparation}

Thoracic rat aorta was removed, cleaned and sectioned in ring segments (3-5 mm). Aortic rings were mounted for tension recording $(2 \mathrm{~g})$ in organ baths filled with modified Tyrode solution (in mM: $136 \mathrm{NaCl}, 5 \mathrm{KCl}, 0.98 \mathrm{MgCl}_{2}, 2 \mathrm{CaCl}_{2}, 0.36 \mathrm{NaH} 2 \mathrm{PO} 4$, $11.9 \mathrm{NaHCO} 3$, and 5.5 glucose) at $37^{\circ} \mathrm{C}, 95 \% \mathrm{O} 2$ and $5 \% \mathrm{CO} 2$, $\mathrm{pH}=7.4$. Aorta was challenged with $\mathrm{KCl}(60 \mathrm{mM})$ after at least $45 \mathrm{~min}$ of equilibrium to assure tissue viability. The contractile response was measured using a force transducer, coupled to a pre-amplifier and computerized data acquisition system (Chart PanLab). Remotion of endothelium was assessed by mechanical rubbing of the aorta intimal surface. The intact endothelium was considered for relaxant responses to ACh greater than $75 \%$ of the Phe-induced tone ${ }^{12}$.

\section{Investigation of LAL relaxant effect in isolated aorta}

Cumulative concentration of LAL $(0.1-100 \mu \mathrm{g} / \mathrm{ml})$ were performed at the contraction plateau induced by Phe $(0.1$ $\mu \mathrm{M})$ or at aorta basal tonus in either endothelium intact or denuded. Control group received the same volume of Tyrode. The participation of lectin domain was assessed by the previous incubation of $\operatorname{LAL}(30 \mu \mathrm{g} / \mathrm{ml})$ in solution with GIcNAc $(0.1 \mathrm{M})$ for $60 \mathrm{~min}$ at $37^{\circ} \mathrm{C}$, to allow lectin-sugar interactions, before performing experimental protocols. LAL and GICNAc were also incubated in separated solutions at the same conditions as controls. For the involvement of EDRF in the lectin relaxation, inhibitors of NOS (L-NAME; $100 \mu \mathrm{M}$ ), cyclooxygenase (indomethacin; $10 \mu \mathrm{M})$, guanylyl cyclase (ODQ; $10 \mu \mathrm{M})$, muscarinic receptor (atropine; $1 \mu \mathrm{M}$ ), or potassium channels (TEA; $5 \mathrm{mM}$ ) were added to the endothelized tissues $30 \mathrm{~min}$ before Phe.

\section{Statistical analysis}

Data was presented as Mean \pm S.E.M $(n=4-6)$ and analyzed by Student's t test or ANOVA, followed by Bonferroni's post-test, being considered significant $p$ values less than 0.05 .

\section{RESULTS}

\section{LAL induces relaxation in endothelized aorta}

Phenylephrine induced tonic contractions in aorta with amplitude of $0.87 \pm 0.04 \mathrm{~g}(\mathrm{n}=13)$ in the absence and $0.54 \pm 0.03$ $\mathrm{g}(\mathrm{n}=11)$ in the presence of endothelium. Cumulative addition of $\mathrm{LAL}$ to precontracted tissues did not affect endotheliumdenuded preparations (Figure $1 \mathrm{~A}, \mathrm{C}$ ). The aorta basal tonus was also not altered by LAL (data not shown). However, in aorta with intact endothelium, LAL induced significant relaxation that was initiated at $0.1 \mu \mathrm{g} / \mathrm{ml}$ and attained maximal effect at $100 \mu \mathrm{g} /$ $\mathrm{ml}$ by $62.57 \pm 7.8 \%(\mathrm{IC} 50=9.75 \pm 7.1)$ (Figure $1 \mathrm{~B}, \mathrm{C})$. $\mathrm{LAL}$ did not alter the tissue responsiveness, since, at the end of each experiment, $\mathrm{KCl}$-contractile response was similar to the initial tone (Figure 1A, B).

\section{The relaxant effect of LAL was inhibited by GICNAC and EDRF blockers}

The relaxant effect induced by $\mathrm{LAL}$ at $30 \mu \mathrm{g} / \mathrm{ml}(52.49 \pm 10.32$ $\%)$ was abolished by previous incubation with GIcNAc, atropine or ODQ (Figure 2A). LAL relaxant effect (IC50 $9.75 \pm 7.1$ ) at the doses of 10,30 and $100 \mu \mathrm{g} / \mathrm{ml}$ was partially reversed by indomethacin (IC50 LAL + indomethacin: $30.47 \pm 10.93$ ) and abolished by L-NAME and TEA (Figure $2 \mathrm{~B}$ ). 
Figure 1. LAL induces relaxation in endothelized aorta precontracted with phenylephrine. Typical traces of cumulative addition of LAL $(0.1-100 \mu \mathrm{g} / \mathrm{ml})$ to precontracted tissues in (A) denuded or (B) endothelized aorta; (C) Comparison of LAL response in denuded ( $E-)$ or endothelized ( $E+$ ) aorta. Mean \pm S.E.M. $(n=5-7) ;{ }^{*} p<0.05$ vs. $100 \%$ Phe-induced contraction. Phenylephrine (Phe: $0.1 \mu \mathrm{M})$; acetylcholine $(\mathrm{ACh}: 1 \mu \mathrm{M})$, potassium chloride $(\mathrm{KCl}: 60 \mathrm{mM})$; washing with Tyrode $(\mathrm{W})$.

A)

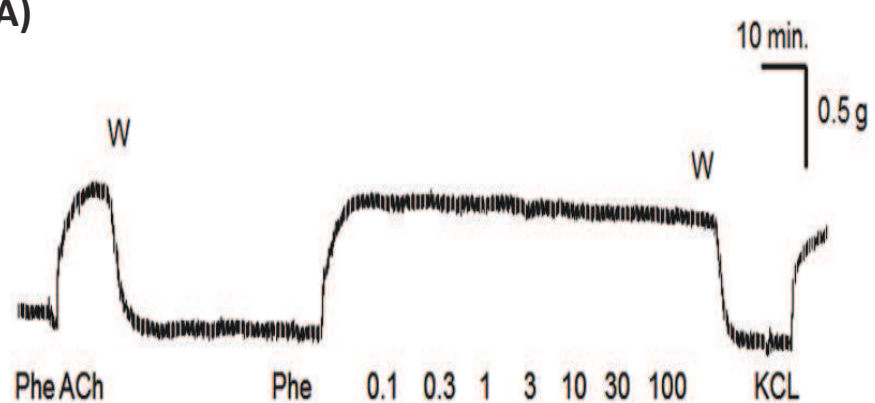

B)

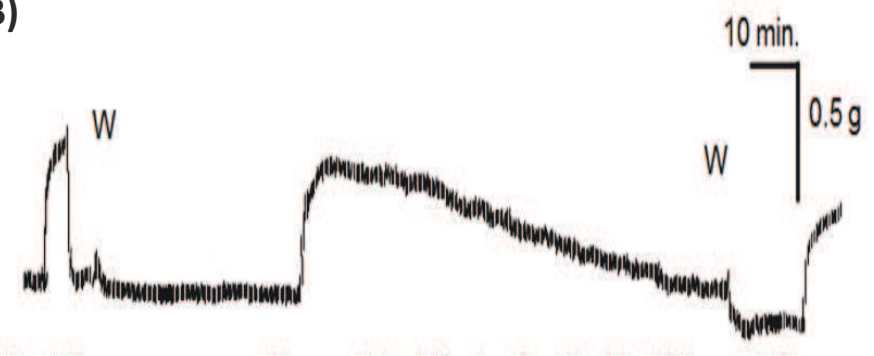

PheACh
Phe $\quad 0.10 .311301030100$
KCL

$\operatorname{LAL}(\mu \mathrm{g} / \mathrm{ml})$

$\mathrm{LAL}(\mu \mathrm{g} / \mathrm{ml})$

C)

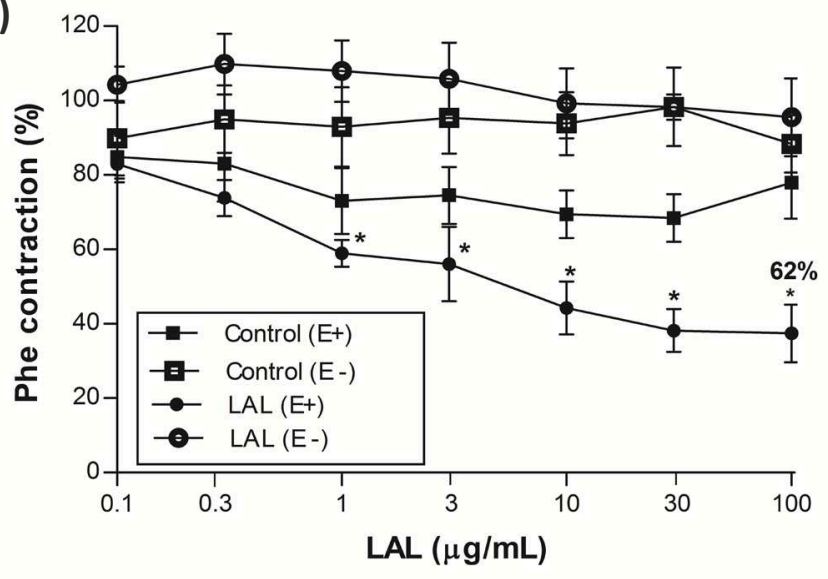

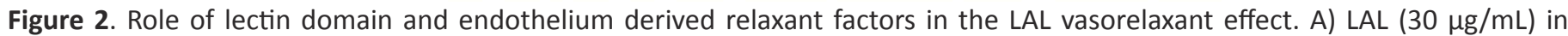
presence of GlcNAc, $1 \mathrm{H}$-[1,2,4]Oxadiazolo-[4,3-a]quinoxalin-1-one (ODQ: $10 \mu \mathrm{M})$ and atropine $(1 \mu \mathrm{M})$; B) LAL (10-100 $\mu \mathrm{g} / \mathrm{mL})$ in presence of INDO, TEA or L-NAME. Mean \pm S.E.M. ( $n=5-7) ;{ }^{*} p<0.05$ vs. control ( $100 \%$ Phe-induced contraction); \#p<0.05 vs. LAL. $\mathrm{N}$-acetyl-glucosamine (GIcNAc: $0.1 \mathrm{M})$; Phenylephrine (Phe: $0.1 \mu \mathrm{M})$; acethylcholine (ACh: $1 \mu \mathrm{M})$; potassium chloride (KCl: $60 \mathrm{mM})$; indomethacin (INDO: $10 \mu \mathrm{M}$ ); tetraethylammonium (TEA: $500 \mu \mathrm{M})$; N-nitro-L-arginine methyl ester (L-NAME: $100 \mu \mathrm{M})$.
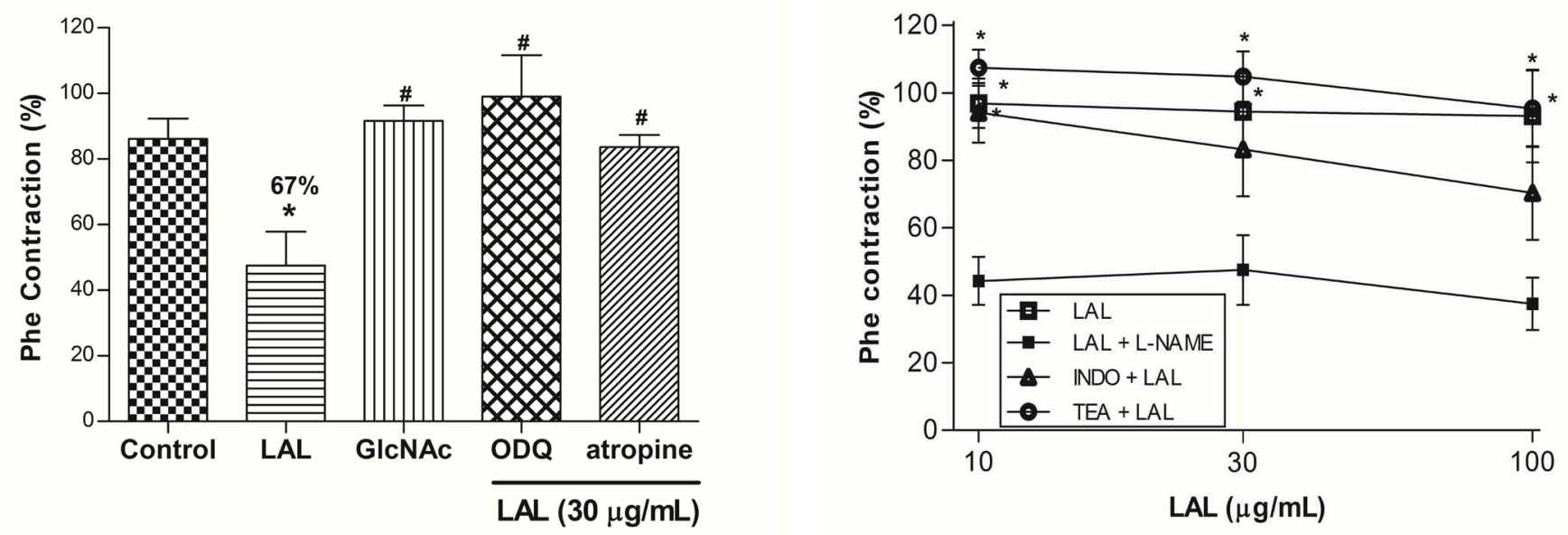


\section{DISCUSSION}

The present study demonstrated that the lectin of Lonchocarpus araripensis (tribe Dalbergieae) induces relaxation in precontracted aorta via lectin domain, an effect strictly dependent on the intact endothelium. Other leguminous lectins had induced relaxation in rat endothelized aorta with the involvement of carbohydrate binding sites ${ }^{4,5,13,14}$, including the lectin of Vatairea guianensis also belonging to the tribe Dalbergieae ${ }^{7}$.

Endothelium-dependent vasodilation is mediated by factors such as nitric oxide (NO), prostacyclin and endotheliumderived hyperpolarizing factor (EDHF) ${ }^{15}$. Many studies have shown that leguminous lectins, similar to $L A L$, present as the main mechanism the induction of relaxation of endothelized aorta the NO pathway ${ }^{4,5}$. It is well known that NO, the principal endothelial relaxant factor, is produced via eNOS activation in response to agonists such as acetylcholine, bradykinin and substance $P$, or via mechanical stimulation, such as shear stress ${ }^{16}$. After diffusion into adjacent smooth muscle cells, NO activates the soluble guanylate cyclase, leading to the increase of intracellular cGMP and relaxation ${ }^{17}$.

In this study, the demonstration of the blockade of LAL-induced relaxation with L-NAME, and also by GICNAc suggests the lectin interaction with carbohydrate sites present in endothelial cells, leading to NO release. In fact, previous evidence had suggested the binding of lectins to vascular endothelial cells via carbohydrate residues ${ }^{18,19}$.

Once the participation of NOS in the LAL effect hab been demonstrated, aortas were incubated with atropine, antagonist of muscarinic receptors of acetylcholine, and ODQ, guanylyl cyclase blocker. Atropine abolished the relaxing effect of LAL on endothelized aortas, as previously observed in other leguminous lectins, such as Pisum arvense ${ }^{6,20}$. This $L A L$ effect was also abolished by tissue incubation with ODQ, showing the participation of the enzyme guanylyl cyclase in the relaxing effect of LAL. Previous evidence suggests that lectins can bind to vascular endothelial cells ${ }^{19}$, which may result in NO release and activation of guanylate cyclase in vascular smooth muscle, reduction in calcium concentration and the consequent vascular relaxation ${ }^{21,22}$.

In addition, indomethacin partially reduced LAL relaxant effect, indicating the participation of prostacyclin, the major product of ciclooxygenase pathway in endothelial cells ${ }^{23}$, that mediates relaxation via activation of adenylyl cyclase increasing cAMP in vascular smooth muscles ${ }^{24}$. The Moreover, LAL-induced relaxation was also blocked by tetraethylammonium, suggesting the participation of EDHF, which promotes dilatation of vascular smooth muscle via $\mathrm{K}+$ channels activation and membrane hyperpolarization ${ }^{25}$. The participation of prostacyclin and EDHF in the relaxant effect of leguminous lectins had already been described ${ }^{4}$.

Studies have shown the association of NO, prostacyclin and EDHF in vasorelaxation. Prostacyclin facilitates NO release from endothelial cells ${ }^{23}$, which activates cGMP synthesis, inhibits phosphodiesterase and inactivates $\mathrm{CAMP}^{26,27}$, potentiating prostacyclin effects in the smooth muscle. Other studies had described the direct activation of $\mathrm{Ca} 2+$ dependent $\mathrm{K}+$ channels (Kca) via NO excluding $\mathrm{CGMP}^{28}$. This connection between NO and EDHF could explain the abolishment of LAL relaxant effect by L-NAME or TEA.

In conclusion, LAL exhibits vasorelaxant activity in phenylephrine-contracted endothelized aorta of rats, involving the lectin domain, muscarinic receptor of acetylcholine and endothelial derived relaxing factors.

\section{ACKNOWLEDGMENTS}

Conselho Nacional de Desenvolvimento Científico e Tecnológico (CNPq), Coordenação de Aperfeiçoamento de Pessoal de Nível Superior (CAPES), Fundação Cearense de Apoio ao Desenvolvimento Científico e Tecnológico (FUNCAP).

\section{REFERENCES}

1. Peumans WJ, Van Damme EJ. Lectins as plant defense proteins. Plant Physiol. 1995 Oct; 109(2):347-352. PubMed Central PMCID : PMC157596.

2. Cavada BS, Barbosa T, Arruda S, Grangeiro TB, Barral-Netto M. Revisiting proteus: Do minor changes in lectin structure matter in biological activity? Lessons from and potential biotechnological uses of the Diocleinae subtribe lectins. Curr Protein Pept Sci. 2001 Jun; 2(2):123-135. PubMed PMID: 12370020.

3. Gadelha CA, Moreno FB, Santi-Gadelha T, Cajazeiras JB, Rocha BA, Assreuy $A M$, et al. Native crystal structure of a nitric oxide-releasing lectin from the seeds of Canavalia maritima. J Struct Biol. 2005 Dec; 152(3):185-194.

4. Assreuy AM, Fontenele SR, de Freitas Pires A, Fernandes DC, Rodrigues NV, Bezerra $\mathrm{EH}$, et al. Vasodilator effects of Diocleinae lectins from the Canavalia genus. Naunyn Schmiedebergs Arch Pharmacol. 2009; 380(6):509-521. doi: 10.1016/j.jsb.2005.07.012. PubMed PMID: 16337811.
5. Bezerra MJ, Rodrigues NV, Pires AF, Bezerra GA, Nobre CB, Alencar KL, et al. Crystal structure of Dioclea violacea lectin and a comparative study of vasorelaxant properties with Dioclea rostrata lectin. Int J Biochem Cell Biol. 2013 Apr; 45(4):807-815. doi: 10.1016/j.biocel.2013.01.012. PubMed PMID: 23353644 .

6. Rocha BAM, Barroso-Neto IL, Teixeira CS, Santiago MQ, Pires AF, Souza LA, et al. CRLI induces vascular smooth muscle relaxation and suggests a dual mechanism of eNOS activation by legume lectins via muscarinic receptors and shear stress. Arch Biochem Biophys. 2015 Jan; 565:32-39. doi: 10.1016/j. abb.2014.11.003. PubMed PMID: 25444858.

7. Silva HC, Nagano CS, Souza LAG, Nascimento KS, Isídro R, Delatorre $P$, et al. Purification and primary structure determination of a galactose-specific lectin from Vatairea guianensis Aublet seeds that exhibits vasorelaxant effect. Process Biochem. 2012 Dec; 47(12):2347-2355. doi: https://doi.org/10.1016/j. 
procbio.2012.09.014.

8. Amorim RM, Pires AF, Dos Santos-Nascimento T, Cavada BS, do Nascimento KS, Cajazeiras JB, et al. The leguminous lectin of Lonchocarpus araripensis promotes antinociception via mechanisms that include neuronal inhibition of $\mathrm{Na}(+)$ currents. Inflamm Res. 2016 Sep; 65(9):701-708. doi: 10.1007/s00011016-0951-0. PubMed PMID: 27193121.

9. Alencar NM, Cavalcante CF, Vasconcelos MP, Leite KB, Aragão KS, Assreuy AM, et al. Anti-inflammatory and antimicrobial effect of lectin from Lonchocarpus sericeus seeds in an experimental rat model of infectious peritonitis. J Pharm Pharmacol. 2005 Jul; 57(7):919-922. doi: 10.1211/0022357056352. PubMed PMID: 15969953.

10. Napimoga MH, Cavada BS, Alencar NM, Mota ML, Bittencourt FS, AlvesFilho JC, et al. Lonchocarpus sericeus lectin decreases leukocyte migration and mechanical hypernociception by inhibiting cytokine and chemokines production. Int Immunopharmacol. 2007 Jun; 7(6):824-835. doi: 10.1016/j. intimp.2007.02.001. PubMed PMID: 17466916.

11. Pires AF, Rodrigues NV, Soares PM, Ribeiro RA, Aragão KS, Marinho MM, et al. A novel $\mathrm{N}$-acetyl-glucosamine lectin of Lonchocarpus araripensis attenuates acute cellular inflammation in mice. Inflamm Res. 2016 Jan; 65(1):43-52. doi: 10.1007/s00011-015-0889-7. PubMed PMID: 26546610

12. Furchgott RF, Zawadzki JV. The obligatory role of endothelial cells in the relaxation of arterial smooth muscle by acetylcholine. Nature. 1980 Nov 288(5789):373-376. PubMed PMID: 6253831.

13. Nascimento AS, Gondim AC, Cajazeiras JB, Correia JL, Pires AF, do Nascimento $\mathrm{KS}$, et al. Purification and partial characterization of a novel lectin from Dioclea lasiocarpa Mart seeds with vasodilator effects. J Mol Recognit. 2012 Dec 25(12):657-664. doi: 10.1002/jmr.2222.

14. Barroso-Neto IL, Simões RC, Rocha BA, Bezerra MJ, Pereira-Junior FN, Silva Osterne VJ, et al. Vasorelaxant activity of Canavalia grandiflora seed lectin: A structural analysis. Arch Biochem Biophys. 2014 Feb; 543:31-39. doi: 10.1016/j. abb.2013.12.006. PubMed PMID: 24361256.

15. Vanhoutte PM. Endothelial control of vasomotor function: from health to coronary disease. Circ J. 2003 Jul; 67(7):572-575. PubMed PMID: 12845177.

16. Michiels C. Endothelial Cell Functions. J Cell Physiol. 2003; 196(3):430-443. PubMed PMID: 12891700.

17. Bauer V, Sotníková R. Nitric oxide - the endothelium-derived relaxing factor and its role in endothelial functions. Gen Physiol Biophys. 2010 Dec; 29(4):319340. PubMed PMID: 21156995.
18. Mills AN, Haworth SG. Changes in lectin binding patterns in the developing pulmonary vasculature of the pig lung. J Pathol. 1986 Jul; 149(3):191-199. doi: 10.1002/path.1711490305.

19. Simionescu M, Simionescu N, Palade GE. Differentiated Microdomains on the Luminal Surface of Capillary Endothelium: distribution of lectin receptors. J Cell Biol. 1982 Aug; 94(2):406-413. PubMed PMID: 7107706.

20. Assreuy AMS, Pinto NV, Mota MRL, Passos Meireles AV, Cajazeiras JB, Nobre CB, et al. Vascular Smooth Muscle Relaxation by a Lectin from Pisum arvense: Evidences of Endothelial NOS Pathway. Protein Pept Lett. 2011Nov; 18(11):1107-1111. PubMed PMID: 21675947.

21. Karaki H1, Ozaki H, Hori M, Mitsui-Saito M, Amano K, Harada K, et al. Calcium movements, distribution, and functions in smooth muscle. Pharmacol Rev. 1997; 49(2):157-230. PubMed PMID: 9228665.

22. Moncada S, Palmer RM, Higgs EA. Nitric oxide: physiology, pathophysiology, and pharmacology. Pharmacol Rev. 1991 Jun; 43(2):109-142. PubMed PMID: 1852778.

23. Mollace V, Muscoli C, Masini E, Cuzzocrea S, Salvemini D. Modulation of Prostaglandin Biosynthesis by Nitric Oxide and Nitric Oxide Donors. Pharmacol Rev. 2005 Jun; 57(2):217 - 252. doi: 10.1124/pr.57.2.1. PubMed PMID: 15914468.

24. Coleman RA, Smith WL, Narumiya S. International union of pharmacology classification of prostanoid receptors and their subtypes. Pharmacol Rev. 1994 Jun; 46(2):205-229. PubMed: 7938166.

25. Inokuchi K, Hirooka Y, Shimokawa H, Sakai K, Kishi T, Ito K, et al. Role of Endothelium-Derived Hyperpolarizing Factor in Human Forearm Circulation. Hypertension. 2003; 42(5):919-924. doi: 10.1161/01.HYP.000009754892665.16.

26. Delpy E, Coste H, Gouville AC. Effects of cyclic GMP elevation on isoprenalineinduced increase in cyclic AMP and relaxation in rat aortic smooth muscle: role of phosphodiesterase 3. Br J Pharmacol. 1996 Oct; 119(3):471-478. PubMed PMID: 8894166.

27. Salvemini D, Currie MG, Mollace V. Nitric oxide-mediated cyclooxygenase activation. A key event in the antiplatelet effects of nitrovasodilators. J Clin Invest. 1996 Jun; 97(11):2562-2568. doi: 10.1172/JCI118704.

28. Bolotina VM, Najibi S, Palacino JJ, Pagano PJ, Cohen RA. Nitric oxide directly activates calcium-dependent potassium channels in vascular smooth muscle. Nature. 1994 Apr; 368(6474):850-853. doi: 10.1038/368850a0. PubMed PMID: 7512692.

\section{Como citar este artigo/How to cite this article:}

Pires AF, Almeida LM, Silva DHM, Marques GFO, .Cajazeiras JB, Cornevile Correia-Neto C, et al. The lectin isolated from Lonchocarpus araripensis seed elicits endothelium-dependent vasorelaxation. J Health Biol Sci. 2017 Jan-Mar; 5(4): 306-310 